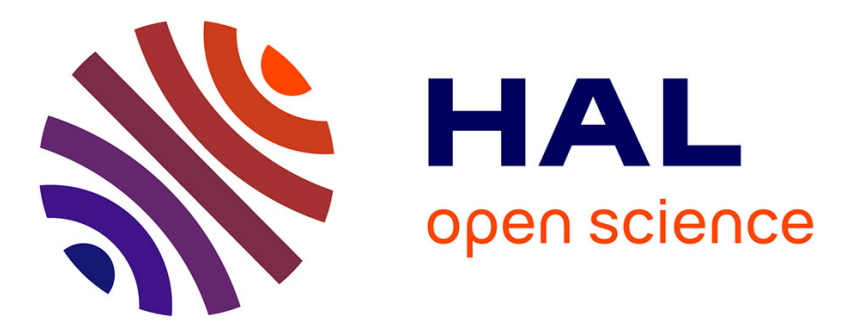

\title{
Carbon and nitrogen removal from a synthetic dairy effluent in a vertical-flow fixed bed bioreactor
}

A. Hamdani, A. Amrane, I. Kader Yettefti, M. Mountadar, O. Assobhei

\section{To cite this version:}

A. Hamdani, A. Amrane, I. Kader Yettefti, M. Mountadar, O. Assobhei. Carbon and nitrogen removal from a synthetic dairy effluent in a vertical-flow fixed bed bioreactor. Bioresource Technology Reports, 2020, 12, pp.100581. 10.1016/j.biteb.2020.100581 . hal-03003352

\section{HAL Id: hal-03003352 \\ https://hal.science/hal-03003352}

Submitted on 18 Nov 2020

HAL is a multi-disciplinary open access archive for the deposit and dissemination of scientific research documents, whether they are published or not. The documents may come from teaching and research institutions in France or abroad, or from public or private research centers.
L'archive ouverte pluridisciplinaire HAL, est destinée au dépôt et à la diffusion de documents scientifiques de niveau recherche, publiés ou non, émanant des établissements d'enseignement et de recherche français ou étrangers, des laboratoires publics ou privés. 


\title{
Carbon and nitrogen removal from a synthetic dairy effluent in a vertical-flow fixed bed bioreactor
}

\author{
Ahmed Hamdani ${ }^{a, b, c^{\star}}$, Abdeltif Amrane ${ }^{d}$, Imane Kader Yettefti ${ }^{c}$, Mohammed Mountadar ${ }^{a}$, Omar \\ Assobhei $^{\mathrm{e}}$ \\ a: Chouaib Doukkali University, Faculty of Science, Laboratory of Water and Environment, PO. Box 20, El Jadida, \\ Morocco. \\ b: Research Group "ESIEF", Regional Center for the professions in Education and Training, Casablanca-Settat, \\ PO. Box 291, Morocco. \\ c: Chouaib Doukkali University, Faculty of Science, Laboratory BIOMARE, PO. Box 20, El Jadida, Morocco. \\ d: Université de Rennes, Ecole Nationale Supérieure de Chimie de Rennes, CNRS, ISCR-UMR 6226, F-35000 \\ Rennes, France. \\ e: Sidi Mohamed Ben Abdellah University, Presidency, Imouzzer Route, PO. Box 2626, Fez, Morocco.
}

* Corresponding author: a_hamdani04@hotmail.com; Tel.: (00212) 670565050
A. Amrane (abdeltif.amrane@univ-rennes1.fr)
I. Kader Yettefti (imanekaderyettefti@gmail.com)
M. Mountadar(mounta_dar@yahoo.fr)
O. Assobhei (assobhei1@yahoo.fr)

Author Contributions: All authors contributed to the study, read, and approved the submitted version of the manuscript for publication to "Bioresource Technology Reports". 


\section{$\underline{\text { Abstract }}$}

In this study, a synthetic dairy effluent (SDE) containing high levels of COD and nitrogen was treated in a fixed-bed bioreactor (FBBR) under the influence of the variations in residence time, aeration conditions and temperature. The tests performed continuously in a single step and the same reaction vessel allowed to define a $96 \mathrm{~h}$ cycle comprising two anoxic/aerobic phases of $48 \mathrm{~h}$ each. Sequential anoxic and aerobic conditions improved the removal of TKN and $\mathrm{NH}_{4}{ }^{+}$by a factor of 2.5 , whereas low temperature significantly decreased the nitrogen and COD removal rate. Overall, outcomes showed a successful growth of the biomass that reached $(5.8 \pm 0.31) \times 10^{6} \mathrm{CFU} / \mathrm{mL}$, and high removal efficiency of $\operatorname{COD}(93.5 \pm 8.1 \%), \mathrm{NO}_{3}{ }^{-}(99.2 \pm 19 \%)$, $\mathrm{TKN}(87.5 \pm 16.1 \%)$, and $\mathrm{NH}_{4}{ }^{+}(55.8$ $\pm 8.3 \%$ ), and hence complied with Moroccan standards. The FBBR system, therefore, can be applied successfully to remove COD and nitrogen from wastewater.

Keywords: biological treatment, COD, fixed-bed bioreactor, heterotrophic flora, nitrogen, wastewater. 
Paper Hamdani et al.

\section{Introduction}

Today, most Human activities whether domestic, industrial, agricultural, or touristic have not only enhanced the life quality, but also resulted in the release of wastewater pollutants on the environment and the public health. Human health risk associated with polluted water is one of the major challenges that humanity will face in the twenty-first century because of the diversity and hazardous nature of water-polluting components. There are several categories of water pollutants, i.e. nutrients (Carbon $\mathrm{C}$, nitrogen $\mathrm{N}$, phosphorus $\mathrm{P}$ ), micropollutants (heavy metals, pesticides, synthetic hormones...), but also microbiological (bacteria: Fecal coliforms, fecal Streptococci, Salmonella, Vibrio cholera...; viruses: hepatitis virus...; parasites: Ascaris, Taenia...; protozoa: Giardia intestinalis, Entamoeba histolytica...) and physical (thermal pollution, suspended solids, radioactivity...). Special attention is given to the various compounds contained in liquid effluents, which are a substantial pollution source to the aquatic environment (Chen et al., 2020; Metcalf \& Eddy, 2013).

The dairy industry is one of the most important activities causing water pollution due to its high demand for the resources, particularly for water: about $90 \%$ of milk is made of water. Owing to the used raw material and the large amount of water consumed, the dairy factories negatively affect the environment by rejecting great quantities of liquid effluents with a high level of $\mathrm{C}, \mathrm{N}$, and $\mathrm{P}$ (Hamdani et al., 2018; Porwal et al., 2015). These three substances exist naturally at relatively low levels in aquatic environments, once released in large quantities via point source effluents they can have a negative impact on the quality of the receiving environment (malodor, asphyxia, eutrophication...), as well as on people's health and economy (OMS, 2016). To avoid these nuisances, the presence of organic matter, nitrogen, and phosphorus in raw wastewater has been regulated and their levels must be reduced to limit values established by this legislation. Organic matter removal can be provided by physico-chemical processes (oxidation, filtration, flocculation-decantation, photo-catalytic reduction...); however, this kind of treatment has a certain number of disadvantages, including a high cost, excessive sludge production, the use of chemicals agents, secondary pollutants generation, physico-chemical monitoring of the effluent $(\mathrm{pH})$ and above all, only partial treatment (Crini and Lichtfouse, 2019; Hamdani et al., 2005; Porwal et al., 2015). As an indication, the costs of chemicals used in wastewater treatment plant are between $5-15 \%$ of the total project cost (Anand et al., 2012), while the typical water treatment plant produces from 0.4 to $0.8 \mathrm{mg}$ of chemical sludge per $\mathrm{mg}$ of used coagulant (Guimaraes et al., 2016). Hamdani et al., (2005) reported that a cubic meter of dairy effluent treated by using three coagulants generates a sludge in the range of $0.98-1.38 \mathrm{mg}$ of suspended matter per liter of dairy effluent depending on the chemical reagents, and require a cost from 0.01 to 0.25 USD. Van Dongen et al. (2001) reported that the nitrogen conversion process by using biological way is estimated at 1.12 to 1.68 USD $/ \mathrm{kg} \mathrm{N}$ removed compared to 5.6 to $14 \mathrm{USD} / \mathrm{Kg} \mathrm{N}$ removal for a physico-chemical method. These limitations make the biological processes profitable and alternative for wastewater treatment.

Compared to physical and chemical treatment processes, biological methods are considered more attractive, economical and the best adapted alternative for removing biodegradable pollutants, because (i) their principle of treatment is similar to the natural phenomena of water self-purification, (ii) their support on a significant number of microbial species with high biodegradability of organic matter and nutrients (iii) their best pollution abatement rate, (iv) their capacity for generating much high-value-added product, i.e. water, energy, fertilizers, nutrients, and (v) their moderate cost... (Batstone et al., 2015; Crini and Lichtfouse, 2019; Kehrein et al., 2020; Samer, 2015). 
In biological wastewater treatment, soluble and colloidal substances in the effluent are decomposed by the action of a variety of living organisms, i.e. plants (microalgae, aquatic vegetation...), animals (protozoa, invertebrates...), and especially purifying microorganisms which remain by far the main actors involved in the wastewater purification. The purifying microorganisms use their specific metabolism to convert carbonaceous and nitrogenous matter $(C, N, P)$ in the liquid effluents to water, new cells, carbon dioxide, and other stables and harmless end products (Samer, 2015). This mechanism can be explained by the following global equation (1) (Wentzel et al., 2003).

$$
\mathrm{n}_{1}(\text { Organic matter })+\mathrm{n}_{2}\left(\mathrm{NH}_{4}{ }^{+}\right)+\mathrm{n}_{3}\left(\mathrm{O}_{2}\right)+\mathrm{n}_{4}\left(\mathrm{PO}_{4}{ }^{3-}\right) \stackrel{\text { Bacteria }}{\rightarrow} \mathrm{n}_{5}(\mathrm{New} \text { cells })+\mathrm{n}_{6}\left(\mathrm{CO}_{2}\right)+\mathrm{n}_{7}\left(\mathrm{H}_{2} \mathrm{O}\right)
$$

Organic matter degradation involves heterotrophic bacteria, such as Acinetobacter, Achromobacter, Alcaligenes, Bacillus, Flavobacterium, Micrococcus, Pseudomonas...), which use biodegradable carbon and nutrients as a source of food and energy (Metcalf \& Eddy, 2013; Samer, 2015). Based on oxygen availability, two processes can be envisaged: in the presence of oxygen, microorganisms decompose organic matter to meet their needs and produce new living cells. In the absence of oxygen, microbial growth happens when using other final electron acceptors than molecular oxygen like oxygenated mineral compounds (Batstone et al., 2015; Kehrein et al., 2020; Mauffrey, 2016; Russell, 2019). This is the case with biodenitrification, which is an anoxic process where heterotrophic bacteria will be forced to use the oxygen contained in the nitrates (nitrate and nitrite respiration) as the final acceptors of electrons during oxidation reactions of organic substances (Hamdani et al., 2018).

For the biological treatment of organic and nitrogen compounds, many studies have focused on the use of suspended biomass systems such as activated sludge and sequencing batch reactors. These systems, although commonly used for big communes, have some disadvantages: problems related to multiple ponds, recirculation of effluent and biomass, water-sludge separation, sensitivity to the load variations, high costs, maintenance... (Gurtekin, 2014; Nancharaiah and Sarvajith, 2019).

Other researchers studied the application of different configurations of fixed culture reactors in the removal of organic matters and/or nutrient during wastewater treatment, i.e. fixed bed membrane bioreactor (Subtil et al., 2014), ozone fixed bed bioreactor (Liu et al., 2017), Up flow fixed bed bioreactor (Hamdani et al, 2018), immersed bacterial bed reactor (Sylla et al., 2017), hybrid moving fixed bed biofilm reactor (Di Bella and Mannina, 2020), submerged fixed bed biofilm reactor (Schlegel and Koeser, 2009). In all studies, a mean removal efficiencies for COD and total nitrogen in the range of $70-99 \%$ and $20-92 \%$, respectively, were obtained at hydraulic retention times in the range of $36 \mathrm{~h}$ to 6 months.

In Morocco, -which is experiencing a considerable delay in liquid sanitation-, activated sludge, lagoons, settlers-digesters and infiltration-percolation represent around $80 \%$ of all wastewater treatment plants; while bacterial beds are very little represented (Belloulid et al., 2018). Despite the abundance of studies on the subject, only very few investigations focused on environmental impact of Moroccan dairy industry where approximately $4.5 \times 10^{9} \mathrm{~L}$ of processed milk are produced annually in 2020 , and $1500 \mathrm{~L}$ of water is needed to obtain $1 \mathrm{~kg}$ of milk (FAO, 2011). The large majority of the water consumed is returned to the receiving environment in the form of raw effluent high in biological and chemical pollutants.

Hence the objective of this study was to assess the performance of an immobilized biomass bed reactor to remove COD and different forms of nitrogen such as $\mathrm{NO}_{3}{ }^{-}, \mathrm{TKN}$, and $\mathrm{NH}_{4}{ }^{+}$from SDE in a single step and in the same reaction chamber, and under the effect of residence time $(24,48,72,96 \mathrm{~h})$, aeration conditions (anoxic, aerobic, anoxic/anaerobic, anoxic/aerobic modes) and temperature $(10,15$, $\left.20,30^{\circ} \mathrm{C}\right)$. 


\section{Materials and Methods}

\subsection{Pilot description and operating conditions}

Laboratory tests were conducted in a fixed-bed bioreactor, which was a rectangular stainless-steel column with dimension in cm Length $\times$ Width $\times$ Height $=250 \times 250 \times 950$ (Fig. 1).

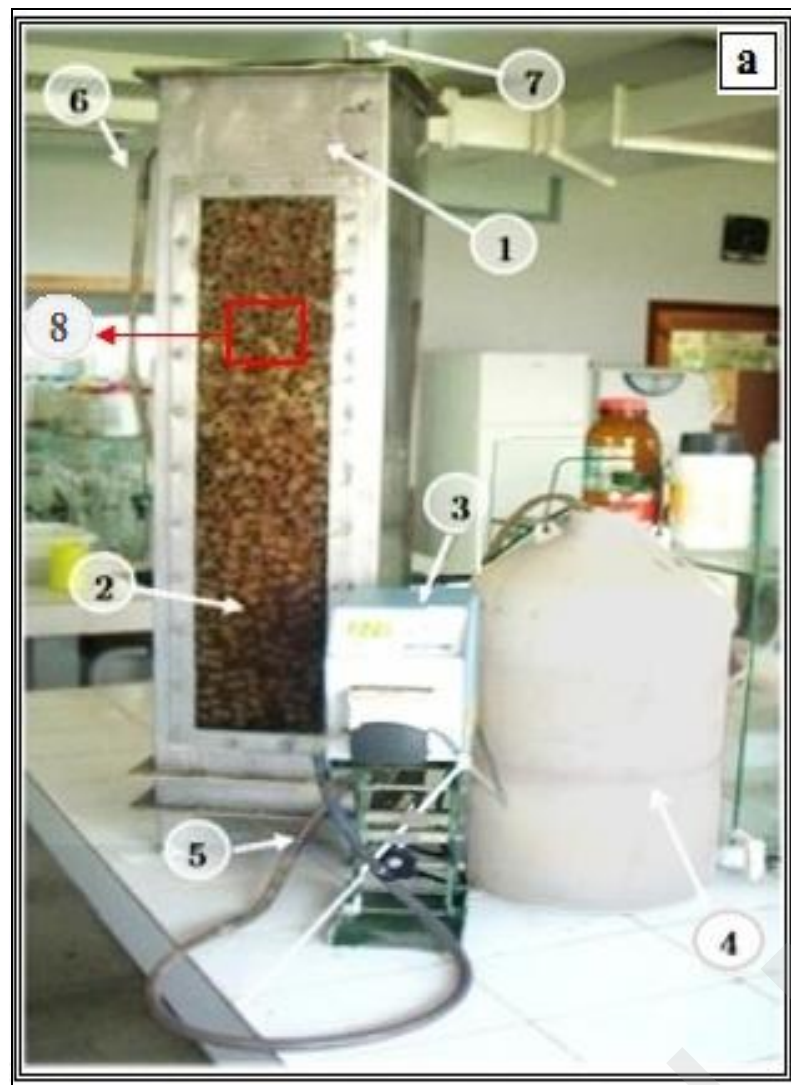

1- Bioreactor, 2- Carrier layer, 3- Feed pump,

4- Influent tank, 5- Connect pump-bioreactor,

6- Effluent outlet, 7- Gas outlet,

8- Biofilm carrier (See detail in graphical abstract)

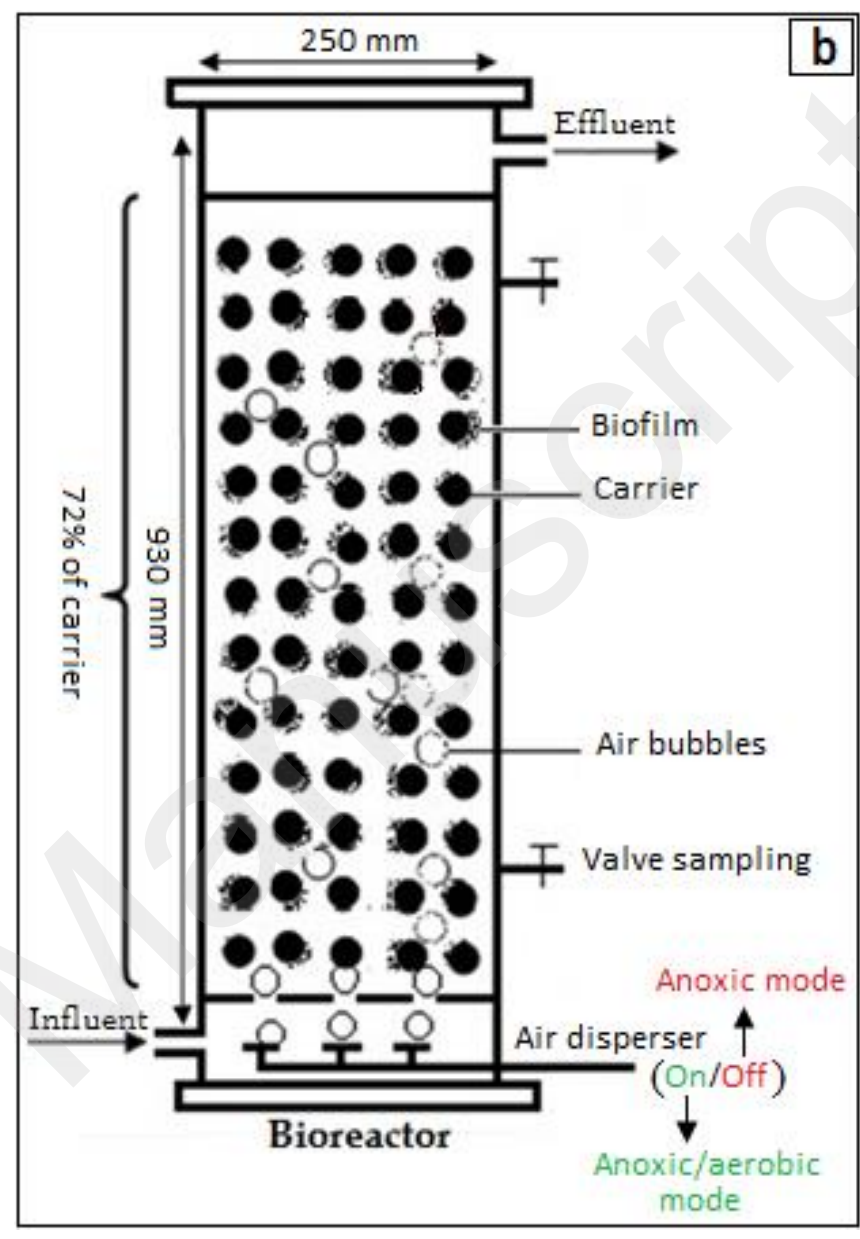

Fig. 1. Experimental system: (a) photography taken in the laboratory and (b) its schematic representation

The bioreactor was filled with food-grade plastic support used as a carrier to biomass immobilization and operated in continuous vertical flow mode. The effective liquid volume of the continuous bioreactor was approximately 60 liters while the apparent volume occupied by the carrier was $51 \mathrm{~L}$ with a vacuum of $44.5 \mathrm{~L}$, which is equivalent to $87 \%$ of porosity. The bioreactor was equipped with a peristaltic pump "Percom N-M" for influent feeding, an aeration system ON/OFF, a valve sampling, and a pipe of $1.5 \mathrm{~cm}$ in diameter for the biogas outlet. To remove undesirable microbes, the column was sterilized with alcohol and then rinsed repeatedly with sterile distilled water, while the carrier was autoclaved at $105^{\circ} \mathrm{C}$ for 30 minutes. The main characteristics of the support material are shown in Table 1.

Table 1. Support material specifications in the bioreactor

\begin{tabular}{ccccccccc}
\hline $\begin{array}{c}\text { Support } \\
\text { material }\end{array}$ & Shape & Color & $\begin{array}{c}\text { Diameter } \\
(\mathrm{mm})\end{array}$ & $\begin{array}{c}\text { Height } \\
(\mathrm{mm})\end{array}$ & $\begin{array}{c}\text { Apparent } \\
\text { volume } \\
(\mathrm{L})\end{array}$ & $\begin{array}{c}\text { Vacuum } \\
(\mathrm{L})\end{array}$ & $\begin{array}{c}\text { Specific } \\
\text { surface } \\
\left(\mathrm{m}^{2} / \mathrm{m}^{3}\right)\end{array}$ & $\begin{array}{c}\text { Porosity } \\
(\%)\end{array}$ \\
\hline Plastic & Ring & White & $16 \times 2$ & $15 \pm 1$ & 51 & 44.5 & 190 & 87 \\
\hline
\end{tabular}


The operating conditions of the experiments are reported in Table 2.

Table 2. Bioreactor operating parameters

\begin{tabular}{|c|c|c|}
\hline \multirow{2}{*}{ Parameter } & \multicolumn{2}{|c|}{ Value } \\
\hline & Anoxic mode & Anoxic/aerobic mode \\
\hline Temperature $\left({ }^{\circ} \mathrm{C}\right)$ & $30( \pm 5)$ & Variable \\
\hline pH & $7( \pm 0.5)$ & $7( \pm 0.5)$ \\
\hline $\mathrm{COD} / \mathrm{NO}_{3}^{-}$Ratio & $5( \pm 1)$ & $5( \pm 1)$ \\
\hline Applied load $\mathrm{NO}_{3}^{-}\left(\mathrm{Kg} / \mathrm{m}^{3} . \mathrm{J}\right)$ & $0.536( \pm 0.09)$ & $0.536( \pm 0.09)$ \\
\hline Applied load COD $\left(\mathrm{Kg} / \mathrm{m}^{3} . \mathrm{J}\right)$ & $2.62( \pm 0.36)$ & $2.62( \pm 0.36)$ \\
\hline Influent flow $(\mathrm{l} / \mathrm{h})$ & 1.5 & 1.5 \\
\hline Flow direction & Up flow & Up flow \\
\hline Theoretical hydraulic retention time (h) & 28.7 & 28.7 \\
\hline Aeration period $(h)$ & 48 & 48 \\
\hline Anoxic period $(\mathrm{h})$ & 48 & 48 \\
\hline Initial biomass (CFU/mL) & {$[2.6( \pm 0.13)] \times 10^{7}$} & {$[2.6( \pm 0.13)] \times 10^{7}$} \\
\hline
\end{tabular}

Values in parenthesis indicate standard error of the mean SEM (a mean of three determinations)

\subsection{Pilot inoculum, feeding and aeration}

The bioreactor was inoculated properly with a bacterial laboratory suspension at approximately (2.6 $\pm 0.13) \times 10^{7} \mathrm{CFU} / \mathrm{mL}$. These bacteria were isolated from sediments and soil sample collected in a decantation pits and storage ponds of effluents produced by a dairy industry located in El Jadida City (Morocco), purified and selected in the BIOMARE laboratory, based on their ability to remove carbon and nitrogen.

The bacterial biomass was left to grow gradually on the inert support in the presence of culture medium enriched in nitrate and organic matter, which was renewed every $48 \mathrm{~h}$. After four weeks, the biofilm had become visible, and a mucilaginous layer appeared on the surface of the garnishing. This duration represents the preculture time required to achieve a steady-state.

An adjustable flow rate peristaltic pump provided the bioreactor with SDE based on milk powder manufactured by Dairy industry unit located in El Jadida City (Morocco) that transited in up-flow through the plastic support previously colonized by the acclimated biomass. The recipe of the reconstituted influent was inspired by those proposed by Nopens et al. (2001) with some modifications to obtain appropriate $\mathrm{COD} / \mathrm{TKN} / \mathrm{TP}$ and $\mathrm{COD} / \mathrm{NO}_{3}{ }^{-}$initial ratios. This model solution whose composition is presented in the Table 3 was prepared with distilled water and had a pH of $7 \pm 0.2$.

Table 3. Composition of the reconstituted dairy effluent

\begin{tabular}{lccccc}
\hline Compounds and & \multicolumn{5}{c}{ Theoretical values of chemical parameters, expressed in $\mathbf{~ m g / L}$} \\
\cline { 2 - 6 } concentration (mg/L) & $\mathrm{COD}$ & $\mathrm{NO}_{3}{ }^{-}$ & $\mathrm{NH}_{4}{ }^{+}$ & $\mathrm{TKN}$ & $\mathrm{TP}$ \\
\hline Nutrient & 750 & 00 & 33 & 45 & 7,5 \\
Milk powder: 750 & 500 & 00 & 00 & 00 & 00 \\
Starch: 500 & 250 & 00 & 23 & 30 & 00 \\
Yeast extract: 250 & & & & & \\
Chemicals & 00 & 00 & 00 & 00 & 2,7 \\
$\mathrm{KH}_{2} \mathrm{PO}_{4}: 20$ & 00 & 00 & 00 & 00 & 4,8 \\
$\mathrm{NaH}_{2} \mathrm{PO}_{4}, 12 \mathrm{H}_{2} \mathrm{O}: 50$ & & & & & \\
\end{tabular}


Paper Hamdani et al.

\begin{tabular}{lccccc}
$\mathrm{NH}_{4} \mathrm{Cl}: 105$ & 00 & 00 & 22 & 30 & 00 \\
$\mathrm{KNO}_{3}: 500$ & 00 & 306.6 & 69 & 69 & 00 \\
Micro-nutrient & & & & & \\
$\mathrm{CuSO}_{4}, 5 \mathrm{H}_{2} \mathrm{O}: 50$ & 00 & 00 & 00 & 00 & 00 \\
$\mathrm{MnSO}_{4}, \mathrm{H}_{2} \mathrm{O}: 100$ & 00 & 00 & 00 & 00 & 00 \\
$\mathrm{ZnSO}_{4}, \mathrm{H}_{2} \mathrm{O}: 100$ & 00 & 00 & 00 & 00 & 00 \\
$\mathrm{FeCl}_{3}, 6 \mathrm{H}_{2} \mathrm{O}: 100$ & 00 & 00 & 00 & 00 & 00 \\
$\mathrm{MoO}_{24}\left(\mathrm{NH}_{4}\right)_{6}, 4 \mathrm{H}_{2} \mathrm{O}: 500$ & 00 & 00 & 13.6 & 10.6 & 00 \\
\hline Total & 1500 & 306.6 & 160.6 & 184.6 & 15 \\
\hline
\end{tabular}

The choice of a model effluent simulating real dairy effluent was justified by the willingness to work with a water of stable of composition, controllable and totally biodegradable, unlike in the case of actual raw dairy effluent, which is characterized by high variability of hourly daytime measurement for flow, temperature, $\mathrm{pH}$, salinity and the pollution load. But also, to avoid technical problems related to the difficulties in taking, transporting and storing samples especially since one of the objectives was to validate the results obtained in previous work (Hamdani et al., 2018). In addition, taking into account the optimal residence time obtained during our previous work (Hamdani et al., 2018), three cycles (short, medium and long) were tested with the aim of allowing the SHF to simultaneously reduce $\mathrm{COD}$ and $\mathrm{NO}_{3}{ }^{-}$ by biodenitrification, which is an anoxic process. However, the abatement of the other forms of nitrogen ( $\mathrm{TKN}$ and $\mathrm{NH}_{4}^{+}$) was researched through the creation of an aeration phase. The oxygen supply was ensured by injecting filtered air in fine bubbles from the base of the reactor to prevent detachment of biofilm and maintain de-aeration in the rest of the bioreactor. The FBBR aeration mode was controlled via the ON/OFF method, i.e. a continuous anoxic mode (OFF) and alternating cycle anoxic/aeration (ON).

The tests were performed at temperatures lower than $30^{\circ} \mathrm{C}$ to be close to the real conditions in the El Jadida city, where the study took place, which is characterized, - according to the climate data of the provincial meteorological Center, - by a semi-arid climate with an average temperature of $13-25^{\circ} \mathrm{C}$.

\subsection{Analytical and microbiological techniques}

The physicochemical and microbiological analyses were determined according to the Standard Methods for the Examination of Water and Wastewater APHA (2012).

Physical and chemical analyses were carried out on the influent and the effluent with the following parameters: Temperature, $\mathrm{pH}, \mathrm{COD}, \mathrm{NO}_{3}{ }^{-}, \mathrm{NO}_{2}{ }^{-}, \mathrm{NH}_{4}{ }^{+}$and $\mathrm{NTK}$. While, the bacteriological analysis was performed on water samples taken from only the treated effluent and focused on a qualitative and quantitative evaluation of the biomass.

Four groups of flora were searched using a basal media, e. i. Heterotrophic plate count agar -HPCA- (Difco Laboratories, USA) which contains: $3 \mathrm{~g}$ peptone, $0.5 \mathrm{~g}$ soluble casein, $0.2 \mathrm{~g}$ dipotassium hydrogen phosphate, 0.05 magnesium sulphate, $0.001 \mathrm{~g}$ ferric chloride, and $15 \mathrm{~g}$ agar per liter of distilled water. The media was adjusted to $\mathrm{pH} 7.2 \pm 0.2$, incubated at $30^{\circ} \mathrm{C}$ for 96 to $168 \mathrm{~h}$ depending on the targeted bacterial groups, and customized by adding selective components or modifying the cultural and incubation characteristics to select each microbial group and restrict a possible contamination by non-targeted microorganisms (Table 4). 
Table 4: Types of flora and each cultivation conditions

\begin{tabular}{lcl}
\hline & Addition & Cultivation \& incubation characteristics \\
\hline $\begin{array}{l}\text { Heterotrophic denitrifying flora } \\
(\mathrm{HDF})\end{array}$ & $\mathrm{HPCA}$ & $\begin{array}{l}\text { - Incubation temperature: } 30^{\circ} \mathrm{C} \\
\text { - Incubation period: for } 24 \text { to } 168 \mathrm{~h}\end{array}$ \\
\hline Aerobic heterotrophic flora $(\mathrm{AHF})$ & $+1 \mathrm{~g} \mathrm{KNO} 3$ & - Nitrate and nitrite reduction tests: Griess \\
Anaerobic heterotrophic flora & - & reagent and zinc powder \\
(ANHF) & - & Incubation at $30^{\circ} \mathrm{C}$ for $96 \mathrm{~h}$ in strict aerobic \\
\hline Aerobic mesophilic flora (AMF) & $\mathrm{HPCA}+1 \mathrm{~g}$ Glucose & $\begin{array}{l}\text { Incubation on anaerobic jar under } \mathrm{N}_{2} / \mathrm{H}_{2} \\
\text { atmosphere at } 30^{\circ} \mathrm{C} \text { for } 96 \mathrm{~h}\end{array}$ \\
\hline
\end{tabular}

Three methods were used to estimate the number of bacteria:

(i) Indirect enumeration of only living cells cultivated on agar media: For the AMF, the aerobic heterotrophic flora and anaerobic heterotrophic flora, the results were expressed in number of colony-forming units (CFU) per $\mathrm{mL}$ of sample, and only the petri dishes whose number of colonies was between 30 and 300 were counted. However, the denitrifying flora was counted according to the Most Probable Number (MPN) method.

(ii) Direct method using epifluorescence microscope, after staining bacteria with acridine orange, which considers both living and dead cells, unlike the indirect counting method. A sample previously prepared according to the method described by Hobbie et al. (1977) is placed between a slide and a coverslip, then observed under a microscope (Olympus $C \times 41$ ) at $\times 100$ and $\times 400$ magnification.

(iii) Optical determination of total biomass concentration: The biomass specific growth rate was estimated by monitoring the absorbance (OD) periodically at $620 \mathrm{~nm}$. One liter of sterile nutrient broth (Difco Laboratories, Detroit, Mich.) was prepared and specifically, two media were used: uninoculated sterile media designed to blank the spectrophotometer, and the other inoculated with bacteria cells. A sample of $2 \mathrm{~mL}$ was taken from the bacterial culture in suspension and transferred into a clean cuvette. Then, changes in the turbidity of the second medium were recorded against the first uninoculated sterile media as the blank. For the total biomass, an absorbance of 1 was equivalent to $5.8 \times 10^{6} \mathrm{CFU} / \mathrm{mL}$.

In order to estimate the bioactivity of the SHF in the FBBR, exogenous respirations of heterotrophic bacteria were monitored over time after adding three sources of biodegradable carbon (Milk powder, Starch, Yeast extract). The dissolved oxygen consumption rate due to the removal of biodegradable substrate was continuously measured in the bioreactor with a WTW Oxi 315i oxygen meter (Weilheim, Germany).

The SDE treatment efficiency was evaluated on grab samples collected from the bioreactor outflow, by measuring the above cited parameters. The biological treatment experiments were achieved when a steady state was almost reached, and the efficiency was analytically appreciated by monitoring the concentration evolution of the already mentioned parameters at the input or untreated effluent $\left(C_{i}\right)$ and at the output or treated effluent $\left(\mathrm{C}_{0}\right)$ of the bioreactor. The abatement effectiveness $(A)$ of these parameters $(\mathrm{x})$ expressed in percentage (\%) was calculated according to the equation 2.

$$
A(\%)=\left[1-\frac{C_{0}(x)}{C_{i}(x)}\right] \times 100
$$

\subsection{Statistical analysis}

The experimental data were analyzed and expressed as the standard error of the mean (SEM). 
To assess the dependence between operating parameters (residence time, temperature, aeration mode) and various parameters to be removed ( $\left.\mathrm{COD}, \mathrm{TKN}, \mathrm{NO}_{3}{ }^{-}, \mathrm{NH}_{4}{ }^{+}\right)$, statistical calculations according to the paired t-test method were carried out by using statistical software for Microsoft Excel XLSTAT 2020.4.1.1026.

\section{Results and Discussion}

\subsection{Composition of the synthetic dairy effluent}

The physical and chemical composition of the SDE used to feed the bioreactor is given in Table 3. In addition to milk powder, the reconstituted dairy effluent contained the main elements necessary for bacterial growth, notably a carbonaceous fraction (starch and yeast extract) leading according to the theoretical calculation to a COD of approximately $1500 \mathrm{mg} / \mathrm{L}$, a mineral fraction composed of a phosphate solution, a solution of trace elements and nitrate. From this, the initial amounts of $\mathrm{TKN} \mathrm{NH}_{4}{ }^{+}$, $\mathrm{NO}_{3}{ }^{-}$and TP were 184.6; 160.6; 306.6 and $15 \mathrm{mg} / \mathrm{L}$, respectively. The respective COD/TKN/TP and $\mathrm{COD} / \mathrm{NO}_{3}{ }^{-}$ratios, close to $100 / 12 / 1$ and 5 , were in favor of a satisfactory biological and denitrifying activity of the influent. The ratios were linked to $C O D$ instead of $B D_{5}$ because the $C O D$ was almost totally biodegradable owing to the biodegradability of the constitutive components (milk powder, starch and yeast extract). Before the biological treatment, the SDE color was milky white, but after treatment it was apparently clear and clean. This change in color might be related to the organic matter break down by the action of SHF. Similar finding was reported by Porwal et al. (2015).

\subsection{Effect of the residence time on bioreactor performance}

Operating in continuous anoxic mode and fed by applying loads of $0.536 \pm 0.09$ and $2.62 \pm 0.36$ $\mathrm{Kg} / \mathrm{m}^{3} . \mathrm{J}$ in $\mathrm{NO}_{3}{ }^{-}$and COD respectively, the bioprocess provides the results shown on Fig. 2.

Fig. 2a indicates that after $24 \mathrm{~h}$ of treatment, the nitrate concentration in the effluent equal to 63 $\mathrm{mg} / \mathrm{L}$ was higher than $45 \mathrm{mg} / \mathrm{L}$, value recommended by the CCME (2012) related to the marine aquatic life protection against the direct toxic effects of nitrate. Biodenitrification occurred to reach its optimum (99.99\%) after $48 \mathrm{~h}$ (Fig. 2b); it was accompanied by the reduction of COD from 1500 to $800 \mathrm{mg} / \mathrm{L}(24 \mathrm{~h}$ ), $214 \mathrm{mg} / \mathrm{L}(48 \mathrm{~h})$ and $102 \mathrm{mg} / \mathrm{L}(96 \mathrm{~h})$.
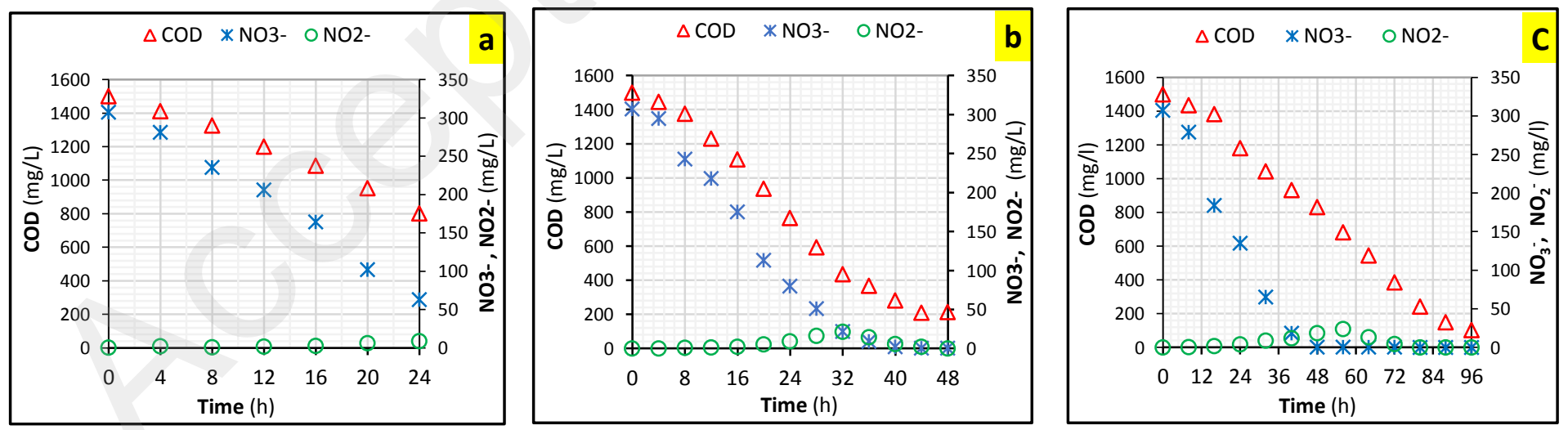

Fig. 2. Variation of nitrate and COD removal efficiency during a (a) $24 \mathrm{~h}$, (b) $48 \mathrm{~h}$ and (c) $96 \mathrm{~h}$ cycle

Thus, to achieve complete biodenitrification, it was necessary to maintain contact between the nitrates, the carbon substrate and the biomass for $48 \mathrm{~h}$; at this moment the COD removal rate was $85.7 \%$. It reached its maximum (93.2\%) after $96 \mathrm{~h}$ of treatment (Fig. $2 \mathrm{c}$ ), thus meeting both the national and the international standards (120 mg/L) (BORM, 2013; Council Directive, 1991). The residence time 
considered (96h) was higher than that described by Casellas (2002), who indicated that a duration of $36 \mathrm{~h}$ is largely sufficient to guarantee a good treatment of organic and nitrogen pollution of urban wastewater.

The recorded performances appear to be comparable to those achieved for the treatment of a raw dairy waste in an anaerobic-aerobic (80:20) immersed bacterial bed: total denitrification in $72 \mathrm{~h}$ coupled with $92 \%$ of COD removal (Hamdani et al., 2018). However, they were slightly above the results reported by Di Bella and Mannina (2020) who obtained a removal of $90 \%$ of nitrates and $93 \%$ of COD during the treatment of synthetic wastewater in a hybrid moving bed biofilm reactor with intermittent aeration. Furthermore, they were noticeably better than those obtained by Sylla et al. (2017), showing reduction of $82.2 \%$ nitrates and $71.5 \%$ COD contained in dairy effluent treated by a submerged bacterial bed, despite the longest period of treatment (42 days).

The high removal efficiencies obtained in this study suggest a high capacity to reduce nitrates and organic matter which is probably favored by:

(i) The selection of natural microbial consortia collected from dairy sludge, and well adapted to grow at the expense of the dairy influent as substrate, especially COD and N. Similar result was found by Porwal et al. (2015) who reported that the isolation of a mixed culture from dairy sludge is a key parameter to remove efficiently COD, and other parameters effectively from dairy effluent.

(ii) The use of inert carrier that offers the possibility to create a wider contact surface between the biofilm and the influent substrate It is helpful for bacterial development and allows their clinging owing to the mucilaginous substance they secrete.

Founding from recent research demonstrated that the application of fixed cell systems offers multiple advantages in wastewater treatment overusing them in their suspended forms: higher mechanical strength, easier biomass/water separation, large increase in volumetric reaction rate, reduction in the size of reactors (Bayat et al., 2015; Martynenko and Gracheva 2003; Velkova et al., 2018). Also, Schlegel and Koeser (2009), and Ibrahim et al. (2019) added that if compared with the suspended one, the immobilized biomass increases more in density per unit bioreactor volume, develops a higher level of metabolic activity, making it possible to consume better the substrate contained in the reaction medium with both lower biomass density and shorter residence times. In this regard, Subtil et al. (2014) indicated that, compared with conventional suspended biomass (5540 \pm 693

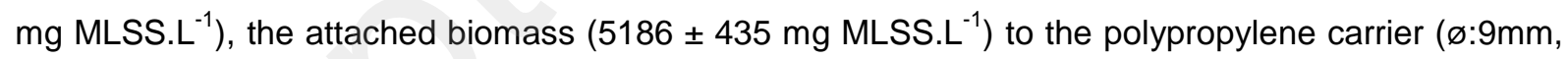
lengths: $10 \mathrm{~mm}$, density: $155 \mathrm{~kg} / \mathrm{m}^{3}$, specific surface area: $330 \mathrm{~m}^{2} / \mathrm{m}^{3}$ ) showed satisfactory removal in COD (96\%), total nitrogen (73\%), and ammonia (98\%) from domestic effluent with only $1 / 3$ of the biomass.

Moreover, the immobilized biomass resists better against toxic compounds (acids, metals...), stress conditions (organic solvent, salinity, inhibiting elements, osmotic pressure, dehydration, self-destruction), and changes in physicochemical parameters ( $\mathrm{pH}$, temperature, $\mathrm{O}_{2} \ldots$ ) (Camargo et al., 2002; Muhamad et al., 2015; Velkova et al., 2018). This is important particularly in favor of wastewater purifying bacteria known for their sensitivity to $\mathrm{pH}$, temperature, oxygen..., that consequently can achieve higher yields. Indeed, Ibrahim et al., (2019) reported that the application of bioreactor provided with polythene support (ø:7mm, height: 10 , density: $155 \mathrm{~kg} / \mathrm{m}^{3}$, a specific surface area $>834 \mathrm{~m}^{2} / \mathrm{m}^{3}$ ) allows the attached biomass to develop better, leading to remove greater than $90 \%$ of both COD, nitrate, nitrite, and ammonia from a synthetic domestic effluent, representing about $12 \%$ more improvement if compared to the unsupported reactor. 
(iii) A supply of exogenous carbon, in sufficient quantity $\left(\mathrm{COD} / \mathrm{NO}_{3}{ }^{-} \simeq 5\right)$, easily and completely

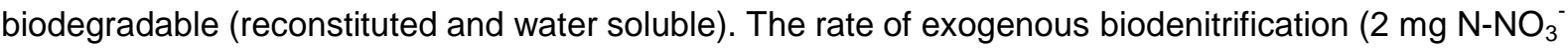
$\left.\mathrm{mgMVS}^{-1} \cdot \mathrm{h}^{-1}\right)$ is considered to be twice as faster, and more efficient than endogenous one $(0.8 \mathrm{mg}$ N-NO3- mgMVS $^{-1} \cdot h^{-1}$ ) for the same operating cycle (Casillas et al., 2002) and it can be up to five times according to Metcalf and Eddy (2013). On the other hand, the biodegradation of organic matter is slower if the available carbon is less rapidly biodegradable (Deronzier et al., 2001). These results are in accordance with those cited by Sylla et al. (2017) and Wang and Chu (2016), showing that biodenitrification is always coupled with the degradation of organic matter and depends on the denitrifying capacities of the bacteria, the nature of the carbonaceous substrate and the residence time.

Besides, the denitrification was concomitant with the progressive formation of nitrite, which reached a maximum between 8.7 and $23.8 \mathrm{mg} / \mathrm{L}$ depending on the operating cycle (Figures $3 \mathbf{a}, 3 \mathbf{b}, 3 \mathbf{c}$ ). However, this formation remained transient since the formed nitrite was completely consumed thereafter. This is in agreement with the results obtained by Pan et al. (2012) who reported that the total elimination of nitrates at pH 6.5 and 7.5 is a guarantee of the absence of the nitrites accumulation in the treated water. Furthermore, the $\mathrm{pH}$ values recorded in this study (between 6.5 and 9) were most likely in favor of a total elimination of the nitrite formed during the denitrification process (see Fig. 2, paragraph 3.2), reflecting a high nitrite reductase activity. Albina et al. (2019) reported that the optimal pH range for complete denitrification without nitrite accumulation is between 7.5 and 9.5. According to Cao et al. (2013), increasing pH during the denitrification process is a good sign of the reduction of nitrites because the denitritation produces alkalinity. Furthermore, Hamdani et al. (2018) indicated that a temperature of $30^{\circ} \mathrm{C}$ promotes a quick and complete nitrite reduction.

Based on these results, only the operating cycle time of $96 \mathrm{~h}$ was therefore considered thereafter.

\subsection{Temperature and $\mathrm{pH}$ evolution on an anoxic $96 \mathrm{~h}$ cycle}

Temperature and $\mathrm{pH}$ are two factors that affect the activity of microorganisms and their living environment.

In this research, the inlet temperature was $30 \pm 5^{\circ} \mathrm{C}$. Fig. 3a shows that the temperature measured at the bioreactor output remained relatively stable, around a value of $28 \pm 2{ }^{\circ} \mathrm{C}$.
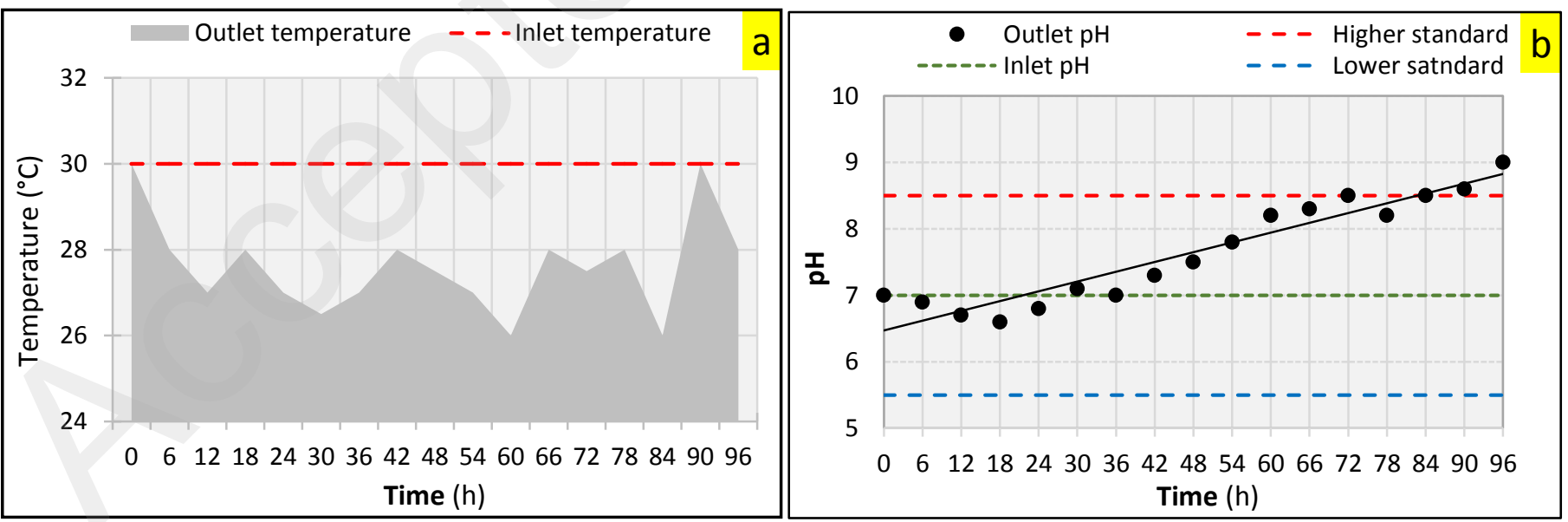

Fig. 3. Evolution over time of (a) the temperature and (b) the $\mathrm{pH}$ at the bioreactor outlet

At the beginning of the treatment, the temperature was supposed to increase because the bacterial growth linked to the degradation of the nutrient substrate is exothermic (Chen et al., 2020). So, this parameter seems to be more impacted by the climate than by endothermic or exothermic reactions 
linked to bacterial metabolism in the reaction medium. The experiments were carried out in El Jadida city (Morocco) during the summer period when the temperature is between 25 and $30{ }^{\circ} \mathrm{C}$, and a natural equilibrium is established between the temperature of the input water and the ambient temperature of the outside environment. Operating at room ambient temperature have the benefit to save energy consumption. The obtained values were very close to the limiting value required by the Moroccan standard $\left(30^{\circ} \mathrm{C}\right)(\mathrm{BORM}, 2013)$ and considered compatible with a good biological activity. Tejaswini et al. (2019) reported that the most operated temperature range in a WWTP varies in the range of 25-30 ${ }^{\circ} \mathrm{C}$.

Fig. $3 \mathbf{b}$ shows that the $\mathrm{pH}$, initially neutral underwent a slight decline to 6.6 during the first $18 \mathrm{~h}$ of treatment, and then tended to increase slightly until reaching 9 at the end of biodenitrification. The acidification noted at the start of denitrification was also noted by Hamdani et al. (2018). It was probably due to the accumulation of $\mathrm{CO}_{2}$ in the reaction medium. Concerning the increase in $\mathrm{pH}$, it comes from the consumption of $\mathrm{H}^{+}$during the biodenitrification reactions (3) (Powers, 2005):

$$
4 \mathrm{NO}_{3}{ }^{-}+5\left(\mathrm{CH}_{2} \mathrm{O}\right)+4 \mathrm{H}^{+} \stackrel{\text { Denitrifying enzymes }}{\longrightarrow} 2 \mathrm{~N}_{2}+5 \mathrm{CO}_{2}+7 \mathrm{H}_{2} \mathrm{O}
$$

Overall, the $\mathrm{pH}$ oscillated between 6.5, value located in the $\mathrm{pH}$ range required by the Moroccan standard (5.5-8.5), and 9, which slightly exceeds the maximum standard set at 8.5 (BORM, 2013). The measured $\mathrm{pH}$ values were compatible with a good activity of SHF.

\subsection{Effect of the aeration mode on the bioreactor performances}

Fig. 4a shows that the COD removal rate depends on the aeration conditions. Compared to the aerobic or anoxic treatment trials where the respective abatement rates were $78 \pm 6.9 \%$ and $82.1 \pm$ $7.2 \%$, the best yields were observed in alternating anoxia either with anaerobic $(94.4 \pm 11 \%)$ or aerobic $(93.5 \pm 8.1 \%)$ modes. COD removal was marked by a drastic decrease, from $1500 \pm 370 \mathrm{mg} / \mathrm{L}$ at the inlet to $84 \pm 26 \mathrm{mg} / \mathrm{L}$ during the anoxic/anaerobic mode and $98.1 \pm 32 \mathrm{mg} / \mathrm{L}$ during the anoxic/aerobic period at the bioreactor outlet, respectively.
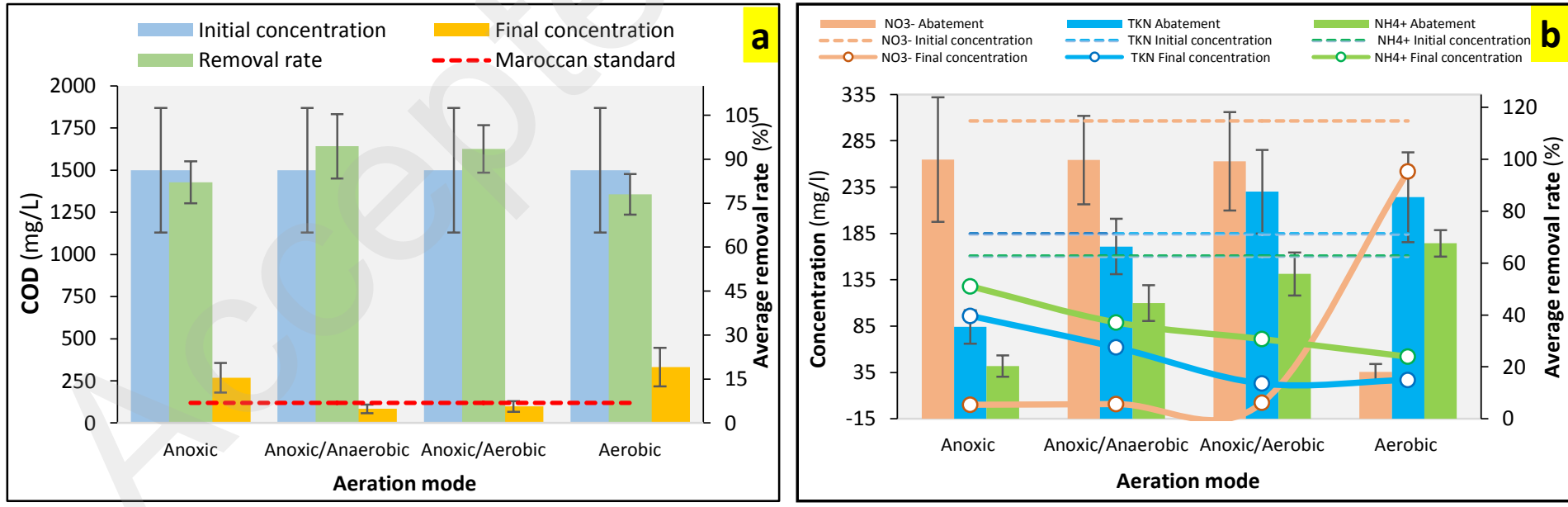

Fig. 4. (a) $\mathrm{COD}$ and (b) nitrogen $\left(\mathrm{TKN}, \mathrm{NO}_{3}{ }^{-}, \mathrm{NH}_{4}{ }^{+}\right)$evolution and removal efficiency over the aeration mode

As shown in Fig. $\mathbf{4 b}$, the pilot bioprocess exposed to total anoxia during $96 \mathrm{~h}$ of operation, allowed the removal of $99.9 \pm 24 \%$ of $\mathrm{NO}_{3}{ }^{-}$; while low abatements were observed for $\mathrm{TKN}$ and $\mathrm{NH}_{4}{ }^{+}$, only $35.4 \pm$ $6.4 \%$ and $20.3 \pm 4.1 \%$ respectively. However, the implementation within the bioreactor of aeration at a rate of $50 \%$ alternating over time with anoxia significantly enhanced the elimination of these forms of 
nitrogen, in addition to a total removal of nitrate: fairly low concentrations of TKN (23 $\pm 0.37 \mathrm{mg} / \mathrm{L})$ and $\mathrm{NH}_{4}{ }^{+}(71 \pm 12.2 \mathrm{mg} / \mathrm{L})$ were recorded for the purified water. The TKN output concentration was below the Moroccan standards (40 mg/L), but slightly higher than the European Communities Directive 91/271/EEC (Council Directive, 1991) (10 to $15 \mathrm{mg} / \mathrm{L}$ ). According to Sawadogo (2018), the integration of anaerobic and aerobic zones inside the same bioreactor promotes an intensive form of biodegradation of organic and nitrogen pollution

The remaining modes (aerobic, anoxic/anaerobic) led to less interesting results in terms of performance: in aerobic, the abatement rate of nitrogen was found relatively high for TKN $(85.4 \pm 17.3$ $\mathrm{mg} / \mathrm{L})$ and $\mathrm{NH}_{4}{ }^{+}(67.6 \pm 5.1 \mathrm{mg} / \mathrm{L})$, but very low for $\mathrm{NO}_{3}{ }^{-}(18 \pm 3.1 \mathrm{mg} / \mathrm{L})$. This shows significant aerobic nitrification and a slight denitrifying activity in the bioreactor. In anoxic/anaerobic mode, the nitrification, which is an aerobic process remained insufficient $(44.6 \pm 6.9 \mathrm{mg} / \mathrm{L})$.

\subsection{Effect of the temperature on the bioreactor performances}

Fig. $5 \mathbf{a}$ and Fig. $5 \mathbf{b}$ show the $\mathrm{COD}$ and nitrogen concentrations ( $\mathrm{TKN}, \mathrm{NH}_{4}{ }^{+}$and $\mathrm{NO}_{3}{ }^{-}$) measured at the input and output of the bioreactor operated in anoxic/aeration mode, at different temperatures, as well as their associated reduction rates.
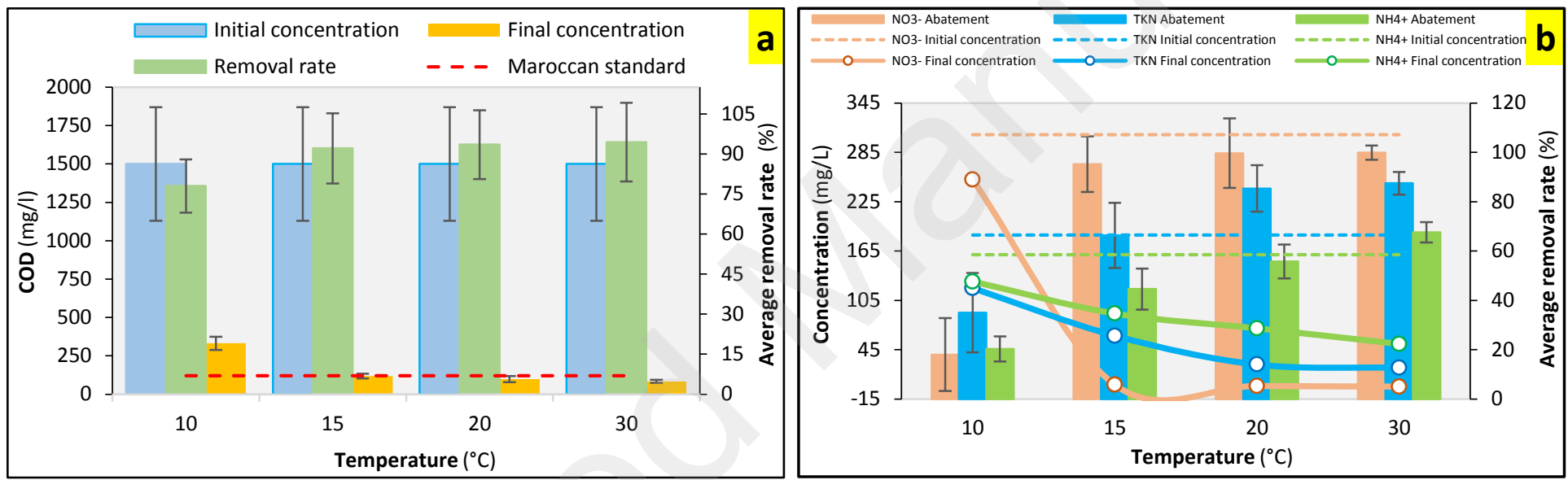

Fig. 5. (a) $\mathrm{COD}$ and (b) nitrogen $\left(\mathrm{TKN}, \mathrm{NO}_{3}{ }^{-}, \mathrm{NH}_{4}{ }^{+}\right)$evolution and removal efficiency over the temperature

As observed in Fig. 5a, the average removal efficiencies of COD decreased as the temperature decreased from $30^{\circ} \mathrm{C}$ to $10^{\circ} \mathrm{C}$. The lowest COD abatement rate $(78 \pm 10 \%)$ corresponded to the lowest temperature $\left(10^{\circ} \mathrm{C}\right)$, while the highest $(94.4 \pm 14.7 \%)$ was recorded at $30{ }^{\circ} \mathrm{C}$ and these high performances were almost kept at $20^{\circ} \mathrm{C}(93.5 \pm 12.9 \%)$, and even at $15^{\circ} \mathrm{C}(92.1 \pm 13.1 \%)$. At $10{ }^{\circ} \mathrm{C}$, the effluent COD content was equal to $332 \pm 42.6 \mathrm{mg} / \mathrm{L}$, exceeding the national and international standard recommended for this parameter $(120 \mathrm{mg} / \mathrm{L})$. This result is similar and even better than that found by Lew et al. (2011) who reported $82 \%, 72 \%, 68 \%$, and $38 \%$ COD removal at $28^{\circ} \mathrm{C}, 20^{\circ} \mathrm{C}, 14{ }^{\circ} \mathrm{C}$, and 10 ${ }^{\circ} \mathrm{C}$ respectively. Similar trend was observed regarding nitrogen removal (Fig. $5 \mathbf{b}$ ), since the best performances were obtained both at 30 and $20^{\circ} \mathrm{C}$ for nitrates $(>99 \%)$ and TKN $(>85 \%)$ and only at 30 ${ }^{\circ} \mathrm{C}$ for $\mathrm{NH}_{4}{ }^{+}(67.6 \pm 5.1 \%)$, while these yields dropped to $35.0 \pm 4.6 \% ; 20.3 \pm 4.1 \%$ and $18.0 \pm 2.9 \%$ for $\mathrm{TKN}, \mathrm{NH}_{4}{ }^{+}$, and $\mathrm{NO}_{3}{ }^{-}$, respectively when the FBBR operated at $10^{\circ} \mathrm{C}$.

If compared to the other related studies, the present findings generally agree with those cited by Lotti et al. (2014) who obtained about $85 \%$ bio-denitrification in a laboratory bioreactor operated at 25 ${ }^{\circ} \mathrm{C}$, which decreased below $20^{\circ} \mathrm{C}$; while Hu et al. (2013) observed $90 \%$ denitrification at $12{ }^{\circ} \mathrm{C}$. These results clearly show that the decrease of temperature from $30^{\circ} \mathrm{C}$ to $10^{\circ} \mathrm{C}$ affected the biological removal 
efficiency which decreased from $99.9 \pm 2.9 \%$ to $18.0 \pm 2.9 \%$ for $\mathrm{NO}_{3}{ }^{-}, 67.6 \pm 5.1 \%$ to $20.3 \pm 4.1 \%$ for $\mathrm{NH}_{4}{ }^{+}$, from $87.5 \pm 4.6 \%$ to $35.0 \pm 4.6 \%$ for TKN, and from $94.4 \pm 14.7 \%$ to $78 \pm 10 \%$ for COD. This represents a decrease of $82 \%, 70 \%, 60 \%$, and $18 \%$ for $\mathrm{NO}_{3}{ }^{-}, \mathrm{NH}_{4}{ }^{+}, \mathrm{TKN}$, and COD respectively. This influence can be explained by a decrease in the metabolic activity of the purifying biomass at low temperature considered damaging for enzymes and cells, which can destabilize the reaction process (Fields, 2001). Hence, it is necessary to maintain an adequate temperature in the bioreactor. However, these results do not agree with those of Arevalo et al. (2014) who demonstrated that variation in temperature has no significant influence on the efficiency of a pilot bioreactor intended to remove COD and the nitrogen contained in domestic wastewater.

\subsection{Correlative statistical analysis}

The results of the statistical analysis presented in Table 5 showed that the efficiency of COD and $\mathrm{NO}_{3}-$ removal was significantly influenced by the residence time: there was a significant difference in the removal efficiencies obtained at $24 \mathrm{~h}, 48 \mathrm{~h}$, and $96 \mathrm{~h}$ ( $\mathrm{p}<0.05$ and observed value $>$ critical value). Also, the efficiency of $\mathrm{COD}, \mathrm{TKN}, \mathrm{NO}_{3}{ }^{-}$and $\mathrm{NH}_{4}{ }^{+}$removal in the effluent depended on the temperature because the average values of removal obtained at $10^{\circ} \mathrm{C}$ were different from those obtained at $15{ }^{\circ} \mathrm{C}$, $20^{\circ} \mathrm{C}$, and $30^{\circ} \mathrm{C}(\mathrm{p}<0.05$ and observed value $>$ critical value $)$. However, except for the reduction of nitrate, the aeration mode had an influence on the removal of COD, TKN, and $\mathrm{NH}_{4}{ }^{+}(p<0.05$ and observed value > critical value). Overall, statistical conclusions seem to be consistent with the experimental results obtained in the present study (Fig. 2a, 2b, 2c; Fig. 4a, 4b; Fig. 5a, 5b).

\subsection{Biomass characteristics}

\subsubsection{Biomass composition}

The examination of the treated water leaving the bioreactor revealed that the biomass was composed of four physiological groups; their respective number and percentage are presented in Table 6.

Table 6. Distribution of the bacterial populations in the effluent according to the counting method

\begin{tabular}{lcccc}
\hline Used method & \multicolumn{2}{c}{ Indirect counting method } & \multicolumn{2}{c}{ Direct counting method } \\
\cline { 2 - 5 } Type of flora & CFU $/ \mathrm{mL}$ & $\%$ & \multicolumn{1}{c}{ Bacteria/mL } & $\%$ \\
Anaerobic heterotrophic flora & {$[8.1( \pm 0.39)] \times 10^{5}$} & $40.5( \pm 5.3)$ & {$[17.6( \pm 0.78)] \times 10^{6}$} & $41.9 \pm 4.1$ \\
Heterotrophic denitrifying flora & {$[5.1( \pm 0.24)] \times 10^{5}$} & $25.5( \pm 2.1)$ & {$[9.8( \pm 0.41)] \times 10^{6}$} & $23.3 \pm 2.7$ \\
Aerobic heterotrophic flora & {$[4( \pm 0.29)] \times 10^{5}$} & $20( \pm 4.6)$ & {$[8.2( \pm 0.45)] \times 10^{6}$} & $19.8 \pm 3.8$ \\
Aerobic mesophilic flora & {$[2.8( \pm 0.15)] \times 10^{5}$} & $14( \pm 1.7)$ & {$[6.4( \pm 0.32)] \times 10^{6}$} & $15 \pm 1.2$ \\
\hline
\end{tabular}

Values in parenthesis indicate standard error of the mean SEM (a mean of three determinations)

In terms of abundance, the results show that the average concentrations of the various bacterial populations measured by direct counting with an epifluorescence microscope were in the range $(6.4 \pm$ $0.32) \times 10^{6}$ (aerobic mesophilic flora) to $(17.6 \pm 0.78) \times 10^{6} \mathrm{CFU} / \mathrm{mL}$ (anaerobic heterotrophic flora). Therefore, they were about an order of magnitude 20 times greater than those counted after cultivation on selective media which varied between $(2.8 \pm 0.15) \times 10^{5}$ and $(8.1 \pm 0.39) \times 10^{5} \mathrm{CFU} / \mathrm{mL}$ (Table 6). This difference between the results given by the two techniques should be most likely related to the fact that the direct methods detect all bacteria present, either alive or dead; while indirect methods underestimate the number of bacteria for two major reasons. First, they count only viable cells, and secondly, they consider that a colony comes from a single cell, which is not always true. 
Table 5. Results of statistical analysis (paired two-samples t-test)

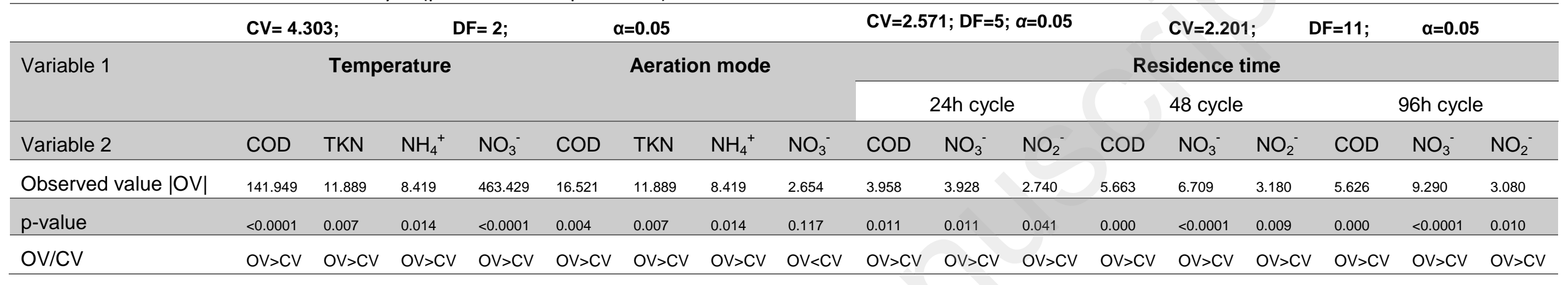

$C V$ : critical value; DF: degree of freedom; $\alpha$ : alpha coefficient 
Qualitatively, the most remarkable observation was the dominance of the anaerobic heterotrophic flora, which represented approximately $40.5 \%$ of the total active biomass colonizing the fixing support. In addition, the density of the aerobic heterotrophic flora was low compared to the anaerobic one. The majority of anaerobic or aerobic heterotrophic bacteria are capable of reducing nitrates to nitrites or nitrogen gas (Mauffrey, 2016). The denitrifying heterotrophic flora, characterized by its ability to use nitrate and other oxygenated mineral nitrogen compounds as the final electron acceptor, was abundant (25.5\% of the total biomass). In this work, after inoculation under already favorable operating conditions of temperature, $\mathrm{pH}, \mathrm{C} / \mathrm{N}$ ratio, and hydraulic residence time, the heterogenous bacterial culture (anaerobic, aerobic, heterotrophic, denitrifiyer...) colonized the carrier, rapidly acclimated, proliferated and developed an immobilized biofilm because they were collected from natural sites of dairy effluent and highly adapted and specialized to grow at the expense of the organic matter and nitrogen. This seems play in favour of a better biodegradation of carbon and nitrogen pollution present in the SDE.

Hall-Stoodley et al. (2004) and Mauffrey (2016) reported that bacterial populations organized in biofilm lifestyle benefit from multiple advantages: stable development, proximity to cells, effective protection against aggressions from the living environment, and finally the emergence of new subpopulations said "persistent" more resistant than regular populations. This results in an increase in their metabolic performance, which promotes the consumption of organic and mineral substrates and improves the yield of the bioreactor. However, further bacterial analysis is needed to identify the species constituting the different groups of bacteria on the carrier media.

\subsubsection{Bioactivity and growth rate determination}

Fig. 6a indicates that the average biodegradation rates of organic substrate in the bioreactor were 76 $\pm 11.64 \%, 53.2 \pm 7.86 \%$, and $47.6 \pm 6.76 \%$ for starch, milk powder, and yeast extract respectively. It is, therefore, preferable to use starch as a source of exogenous organic carbon, since its degradation is rapid by bacteria able to excrete specific enzymes responsible for carbon breakdown. The degradation of milk powder and yeast extract should then take place.
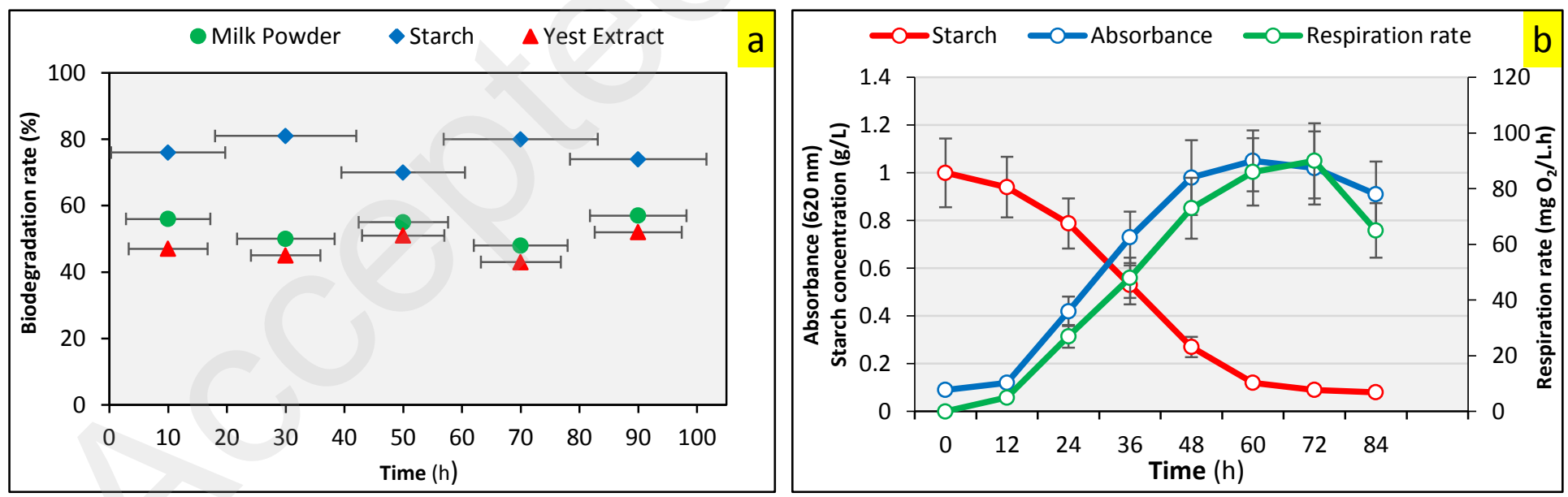

Fig. 6. Changes in (a) starch, milk powder and yeast extract removal rate, and (b) starch concentration, cell growth and respiration rate over the time at $30 \pm 5{ }^{\circ} \mathrm{C}$ and $\mathrm{pH}$ of $7 \pm 0.5$

As shown in Fig $6 \mathbf{b}$, the oxidation of the biodegradable substrate (starch) by heterotrophic biomass was accompanied by cell growth and respiratory activity, expressed in terms of absorbance at $620 \mathrm{~nm}$ and oxygen consumption respectively. After $12 \mathrm{~h}$ of continuous cultivation, the bacterial growth was unrestricted, after which it appeared to be linear from $12 \mathrm{~h}$ to $48 \mathrm{~h}$, and reached its maximum after $60 \mathrm{~h}$ 
$\left.\mathrm{OD}_{620} \simeq 1\right)$, which corresponds according to a calibration curve to approximately $(5.8 \pm 0.31) \times 10^{6}$ $\mathrm{CFU} / \mathrm{mL}$, indicating that a high bioreactor biomass concentration was attained. This is normal because the selected organic substrate (starch) is readily biodegradable by most heterotrophic populations and injected in abundance (1000 mg/L), which explains the increase of biomass concentration and the respiratory activity. This result remains less than $84 \mathrm{~h}$ reported by Hamdani et al. (2018) who worked with a real dairy effluent rich in an organic matter less easily biodegradable if compared to reconstituted synthetic effluent containing starch, milk powder, and yeast extract.

Fig. $6 \mathbf{b}$ also showed that the use in this work of starch as an energy and carbon source satisfies both maximal cellular growth and respiration rates $\left(90 \mathrm{mg} \mathrm{O}_{2} / \mathrm{L}\right.$.h). Degradation of organic matter and nutrient by bacteria needs dissolved oxygen as a final electron acceptor in case of aerobic treatment. When water completely devoid of oxygen (anoxic), bacteria is forced to use the oxygen contained in the nitrates (nitrate respiration). Generally, these processes can be summarized by the aerobic reaction (4) and anoxic reaction (5) (Russel, 2019).

Organics + Bacteria + Nutrients $+\mathrm{O}_{2} \rightarrow$ New cells $+\mathrm{CO}_{2}+\mathrm{H}_{2} \mathrm{O}+$ Residual Organics + Inorganics (4)

Organics + Bacteria $\rightarrow$ New cells + Residual organics $+\mathrm{NH}_{3}+\mathrm{N}_{2}+\mathrm{CO}_{2}+\mathrm{H}_{2} \mathrm{~S}+$ Inorganics (5)

Highly specialized bacteria play a key role in converting organic pollutants into new cells and simple end substances, and thereby producing clean water. Kargi and Pamukoglu, (2003) suggested that in the absence of purifying micro-organisms, the organic COD in wastewater must increase.

\section{Conclusion}

The FBBR anoxic-aerobic bioprocess produced a good quality effluent, which respects the recommended standards. The intermittent aeration was the key to achieve high COD and nitrogen removal efficiency from SDE. This investigation developed in one operating cycle and a single laboratory-scale reactor chamber constitutes the most innovative features of this work for future extrapolation on an industrial scale. This would offer a promising solution in the field of bioremediation, especially for agri-food professionals and small municipality officials in developing countries that suffer from released-raw effluents, limited financial means, lack of qualified human resources, and high-cost land.

\section{Acknowledgments}

The pilot process is part of the "ENVIRONMENT MAROC, FSP RMIE 02/014" project financed by the FSP/SCAC (France) and the CNRST (Morocco).

Special thanks to Professor Abdelmajid KHASSIB, English Teacher in Regional Academy of Education and Training Casablaca-Settat (Morocco) for his elaborative language revision on the paper.

We sincerely thank the anonymous reviewers for their time and useful comments towards the improvement of the manuscript.

\section{CRediT authorship contribution statement}

Ahmed HAMDANI: Conceptualization, Methodology, Investigation, Visualization, Writing-Original draft, Writing-Reviewing and Editing. Abdeltif AMRANE: Visualization, Writing-Reviewing and Editing. Imane KADER YETTEFTI: Resource. Mohammed MOUNTADAR: Resource. Omar ASSOBHEl: Conceptualization, Methodology, Writing-Reviewing and Editing, Supervision. 


\section{Conflicts of Interest}

The authors declare that there is no conflict of interest whatsoever for this paper.

\section{References}

Albina, P., Durban, N., Bertron, A., Albrecht, A., Robinet, J.-C., Erable, B., 2019. Influence of Hydrogen Electron Donor, Alkaline $\mathrm{pH}$, and High Nitrate Concentrations on Microbial Denitrification: A Review. Int. J. Mol. Sci., 20 (20), 5163.

American Public Health Association (APHA), 2012. Standard Methods for the Examination of Water and Wastewater. $22^{\text {th }}$ Edition, APHA-AWWA-WEF, Washington DC, USA, $1360 \mathrm{p}$.

Arevalo, J., Ruiz, L.M., Perez, J., Gomez, M.A., 2014. Effect of temperature on membrane bioreactor performance working with high hydraulic and sludge retention time. Biochem. Eng. J., 88, 42-49.

Batstone, D. J., Hülsen, T., Mehta, C.M., Keller J., 2015. Platforms for energy and nutrient recovery from domestic wastewater: A review, Chemosphere, 140, 2-11

Bayat, Z., Hassanshahian, M., Cappello, S., 2015. Immobilization of Microbes for Bioremediation of Crude Oil Polluted Environments: A Mini Review. Open Microbiol. J., 9, 48-54.

Belloulid, M. O., El Moussaoui, T., Latrach, L., Saykouk, J., El Azzouzi, F., 2018. National Program of Sanitation and Wastewater Treatment in Morocco: Objectives, Achievements and Challenges. Env. Wat. Sci. Pub. H. Ter. Int. J., 2 (1), 67-76.

Bulletin Officiel du Royaume du Maroc (BORM), 2013, № 6202-3 Moharrem 1435 (7-11-2013), p. 2456-2458. 2013.

Camargo, E.F.M., Ratusznei, S.M., Rodrigues, J.A.D., Zaiat, M., Borzani, W., 2002. Treatment of low-strength wastewater using immobilized biomass in a sequencing batch external loop reactor: influence of the medium superficial velocity on the stability and performance. Braz. J. Chem. Eng., 19 (3), 267-275.

Casellas, M., Dagot, C., Baudu, M., 2002. Stratégies d'élimination de l'azote d'un effluent urbain dans un réacteur discontinu séquentiel (SBR). Rev. Sci Eau, 15 (4), 749-765.

Cao, X., Qian, D., Meng, X., 2013. Effects of $\mathrm{pH}$ on nitrite accumulation during wastewater denitrification. Environ Technol., 34 (1), 45-51.

Chen, G.H., Van Loosdrecht, M.C.M., Ekama, G.A., Brdjanovic, D., 2020. Biological Wastewater Treatment: principles, modeling and design. IWA Publishing, $2^{\text {nd }}$ Edition, 866p.

Conseil Canadien des ministres de l'environnement (CCME), 2012. Recommandations canadiennes pour la qualité des eaux : protection de la vie aquatique - nitrate. Information sheet, CCME, Canada, $10 \mathrm{p}$.

Council Directive 91/271/EEC of 21 May 1991 concerning urban waste-water treatment.

Crini, G., Lichtfouse, E., 2019. Advantages and disadvantages of techniques used for wastewater treatment. Environ. Chem. Lett., 17, 145-155.

Deronzier, G., Schétrite, S., Racault, Y., Canler, J.P., Lienard, A., Heduit, A., Duchene, Ph., 2001. Traitement de l'azote dans les stations d'épuration biologique des petites collectivités. Ministère de l'Agriculture et de la Pêche. Document technique FNDAE № 25, Cemagref Editions, France, 79 p.

Di Bella, G., Mannina, G., 2020. Intermittent Aeration in a Hybrid Moving Bed Biofilm Reactor for Carbon and Nutrient Biological Removal. Water, 12 (2), 492.

Fields, P.A., 2001. Protein function at thermal extremes: balancing stability and flexibility. Comp. Biochem. Physiol. A Mol. Integr. Physiol., 129 (2/3), 417-431. 
Food and Agriculture Organization of the United Nations (FAO), 2011. Dairy development in Morocco, by Mohamed Taher Sraïri, Rome, 36p.

Guimaraes N.R., Ferreira Filho S.S., F., Hespanhol, B. P., Piveli, R.P., 2016. Evaluation of chemical sludge production in wastewater treatment processes. Desalination Water Treat., 57(35), 16346-16352.

Gurtekin E., 2014. Sequencing batch reactor, Akademik Platform. In $2^{\text {nd }}$ International Symposium on Environment and Morality ISEM-2014, University Adıyaman, Adıyaman, Turkey, 472-480.

Hall-Stoodley, L., Costerton, J.W., Stoodley, P., 2004. Bacterial biofilms: from the natural environment to infectious diseases. Nat. Rev. Microbiol., 2 (2), 95-108.

Hamdani, A., Mountadar, M., Assobhei, O., 2018. Simultaneous nitrate and organic matter removal from a dairy effluent by biodenitrification. Rev. Sci. Eau, 3 (2), 97-107.

Hamdani, A., Mountadar, M., Assobhei, O., 2005. Comparative study of the efficacy of three coagulants in treating dairy factory waste water. Int. J. Dairy Technol., 58 (2), 83-88.

Hobbie, J.E., Daley, R.J., Jasper, S., 1977. Use of Nuclepore Filters for Counting Bacteria by Fluorescence Microscopy. Appl. Environ. Microbio., 33 (5), 1225-1228.

Hu, Z., Lotti, T., De Kreuk, M., Kleerebezem, R., Loosdrecht, M.V., Kruit, J., Jetten, M.S.M., Kartal, B., 2013. Nitrogen removal by a nitritation-Anammox bioreactor at low temperature. Appl. Environ. Microbiol., 79 (8), 2807-2818.

Ibrahim, R.S., Sabeen, A.H., Noor, Z.Z., Ahmad Mutamim, N.S., 2019. Comparative study of suspended and attached growth in membrane bioreactors for wastewater treatment. Water Environ. J., 0, 1-17.

Kargi, F., Pamukoglu, M.Y., 2003. Aerobic biological treatment of pre-treated landfill leachate by fed-batch operation. Enzyme Microb. Technol., 33, 588-595

Kehrein, P., Van Loosdrecht, M., Osseweijer, P., Garfí, M., Dewulf, J., Posada, J., 2020. A critical review of resource recovery from municipal wastewater treatment plants - market supply potentials, technologies and bottlenecks. Water Res. Technol., 2020, 6, 877-910

Lew, B., Lustig, I., Beliavski, M., Tarre, S., Green M., 2011. An integrated UASB-sludge digester system for raw domestic wastewater treatment in temperate climates. Bioresource Technol., 102 (7), 4921-4924.

Liu, S., Chen, J., Yan, J., Hu, Y., Zhou, D., 2017. Conversion mechanisms of carbon, nitrogen, and phosphorus in ozone-fixed-bed and membrane bioreactors for deep treatment of municipal tail water. Environ. Eng. Sci., 34 (8).

Lotti, T., Kleerebezem, R., Hu, Z., Kartal, B., Jetten, M.S.M., Van Loosdrecht M.C.M., 2014. Simultaneous partial nitritation and anammox at low temperature with granular sludge. Wat. Res., 66 (0), 111-121.

Martynenko, N.N., Gracheva, I.M., 2003. Physiological and biochemical characteristics of immobilized champagne yeasts and their participation in champagnizing processes: A review. Appl. Biochem. Microbiol. 39 (5), 439-445.

Mauffrey, F., 2016. Étude de la voie de dénitrification de la souche bactérienne Methylophaga nitratireducenticrescens JAM1 provenant d'un système de dénitrification d'eau de mer. Thèse de doctorat de type Ph. D, Université du Québec, Canada, 149 p.

Metcalf \& Eddy, 2013. Wastewater engineering: Treatment and Resource Recovery. Mc Graw-Hill Education. 5th Edition, New York, USA, 2048 p. 
Muhamad, M.H., Abdullah, S.R.S., Hasan, H.A., Rahim, R.A.A., 2015. Comparison of the efficiencies of attached- versus suspended-growth SBR systems in the treatment of recycled paper mill wastewater.

J. Environ. Manage., 163, 115-124

Nancharaiah, Y.V., Sarvajith, M., 2019. Aerobic granular sludge process: A fast growing biological treatment for sustainable wastewater treatment. Curr. Opin. Environ. Sci. Health, 12, 57-65.

Nopens, I., Capalozza, C., Vanrolleghem, P.A., 2001. Stability analysis of a synthetic municipal wastewater. Rapport technique, Department of Applied Mathematics Biometrics and Process Control, University of Gent, Gent, Belgique, $23 \mathrm{p}$.

OMS, 2016. La planification de la gestion de la sécurité sanitaire de l'assainissement : Manual for Safe Use and Disposal of Wastewater, Greywater and Excreta. Genève, Suisse, OMS.

Pan, Y., Ye L., Ni, B.-J., Yuan, Z., 2012. Effects of pH on $\mathrm{N}_{2} \mathrm{O}$ reduction and accumulation during denitrification by methanol utilizing denitrifiers. Water Res., 46 (15), 4832-4840.

Porwal, H.J., Mane, A.V., Velhal, S.G., 2015. Biodegradation of dairy effluent by using microbial Isolates obtained from activated sludge. Water Resour. Ind., 9, 1-15.

Powers, S.E., 2005. Quantifying cradle-to-farm gate life-cycle impacts associated with fertilizer used for corn, soybean, and stover production. Technical report NREL/TP-510-37500, National Renewable Energy Laboratory, Golden, CO, USA, $122 \mathrm{p}$.

Russell, D. L., 2019. Practical Wastewater Treatment. Global Environmental Operations Inc. John Wiley \& Sons Inc., Hoboken, NJ, USA: Wiley, 2019, $2^{\text {nd }}$ edition, $480 \mathrm{p}$.

Samer, M., 2015. Chapter: Biological and chemical wastewater treatment. In book: Wastewater Treatment Engineering Publisher, Mohamed Samer (Edits), First Edition. 1-50. IntechOpen, DOI: $10.5772 / 61250$.

Sawadogo, B., 2018. Traitement des eaux usées industrielles par des procédés membranaires sous climat sahélien : cas des eaux usées de brasserie au Burkina Faso. Thèse de doctorat, Institut international d'ingénierie de l'eau et de l'environnement, Université Montpellier, France, 177p.

Schlegel, S., Koeser, H., 2009. Wastewater treatment with submerged fixed bed biofilm reactor systems - design rules, operating experiences and ongoing developments. Water Sci. Technol., 55 (8-9), 83-89.

Subtil, E.L., Mierzwa, J.C., Hespanhol, I., 2014. Comparison between a Conventional Membrane Bioreactor (C-MBR) and a Biofilm Membrane Bioreactor (BF-MBR) for domestic wastewater treatment. Brazilian Journal of Chemical Engineering 31(3):683-691

Sylla, A., Aboussabiq, F.Ez., Hassou, N., Rihani, M., Amine, J., Assobhei, O., Etahiri, S., 2017. Denitrification of wastewater treatment plant effluent using anaerobic bacterial bed reactor immersed: operating performance. JUEE, 11 (2), 208-218.

Tejaswini, E., Uday Bhaskar Babu, G., Seshagiri Rao, A., 2019. Effect of temperature on effluent quality in a biological wastewater treatment process. Chem. Prod. Process Model., 15 (1).

Van Dongen, U., Jetten, M.S.M., Van Loosdrecht, M.C.M., 2001. The SHARON anammox process for treatment of ammonium rich wastewater. Water Science and Technology, 44 (1), 153-160.

Velkova, Z., Kirova, G., Stoytcheva, M., Kostadinova, S., Todorova, K., Gochev, V., 2018. Immobilized microbial biosorbents for heavy metals removal. Eng. Life Sci., 18 (12), 871-881.

Wang, J., Chu, L., 2016. Biological nitrate removal from water and wastewater by solid-phase denitrification process. Biotechnol. Adv., 34 (6), 1103-1112. 
Wentzel, M.C., Ekama, G.A., Loewenthal, R.E., 2003. The Handbook of Water and Wastewater Microbiology. Part 1: Basic microbiology, section 9: Fundamentals of biological behaviour and wastewater strength tests. Edited by Ducan Mra and Nigel Horan, 145-173. 
Title of paper: Carbon and nitrogen removal from a synthetic dairy effluent in a vertical-flow fixed bed bioreactor.

Ref. No: BITEB-D-20-00388.

Authors: Ahmed Hamdani, Abdeltif Amrane, Imane Kader Yettefti, Mohammed Mountadar, Omar Assobhei

\section{Credit authorship contribution statement}

Ahmed HAMDANI: Conceptualization, Methodology, Investigation, Visualization, Writing-Original draft, Writing-Reviewing and Editing.

Abdeltif AMRANE: Visualization, Writing-Reviewing and Editing.

Imane KADER YETTEFTI: Resource.

Mohammed MOUNTADAR: Resource.

Omar ASSOBHEI: Conceptualization, Methodology, Writing-Reviewing and Editing, Supervision. 


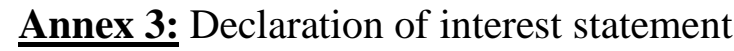

$\underline{\text { Title of paper: }}$ Carbon and nitrogen removal from a synthetic dairy effluent in a vertical-flow fixed bed reactor

Authors: Ahmed Hamdani, Abdeltif Amrane, Imane Kader Yettefti, Mohammed Mountadar, Omar Assobhei

$\bigotimes$ The authors declare that they have no known competing financial interests or personal relationships that could have appeared to influence the work reported in this paper. 


\section{Graphical abstract}

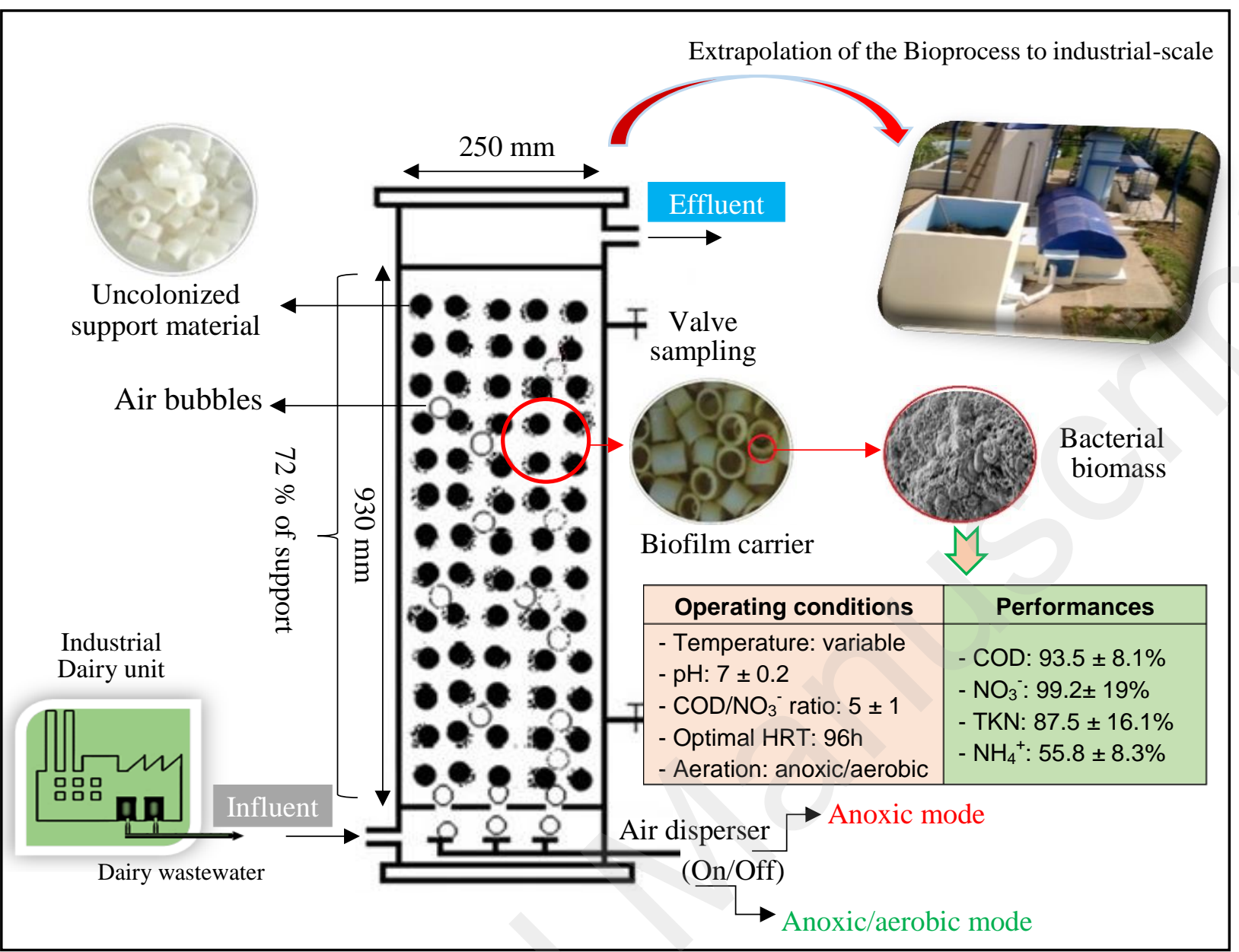


Title of paper: Carbon and nitrogen removal from a synthetic dairy effluent in a vertical-flow fixed bed bioreactor.

Ref. No: BITEB-D-20-00388.

Authors: Ahmed Hamdani, Abdeltif Amrane, Imane Kader Yettefti, Mohammed Mountadar, Omar Assobhei

\section{Article Highlights}

$\checkmark$ Fixed-bed bioreactor was developed for biological carbon and nitrogen removal.

$\checkmark$ Treatment was conducted in one operating cycle and in a single reactor compartment.

$\checkmark$ High and fast growth yields of the biomass were obtained.

$\checkmark$ Anoxic treatment removed $99.9 \pm 24 \%$ of nitrate, and $82.1 \pm 7.2 \%$ of COD.

$\checkmark$ Anoxic/aerobic mode improved both the reduction of TKN and $\mathrm{NH}_{4}{ }^{+}$by 2.5 times. 